\title{
PENGARUH KEPEMIMPINAN, KOMUNIKASI DAN PEMBERIAN REWARD TERHADAP KINERJA PEGAWAI BADAN KOORDINASI WILAYAH II BOJONEGORO PEMPROV JATIM MELALUI MOTIVASI KERJA
}

\author{
Eko Wahyu Hidayat Udjut Saputra ${ }^{1}$ \\ Mei Indrawati ${ }^{2}$ \\ Woro Utari ${ }^{3}$ \\ Program Magister Manajemen \\ Universitas Wijaya Putra Surabaya ${ }^{1}$ \\ email: jualsangatmurah@gmail.com
}

\begin{abstract}
The purpose of this study was to describe the leadership, communication, reward, work motivation and performance of employees in the Bojonegoro Regional Coordinating Board for the East Java Provincial Government. To determine and analyze the influence of leadership, communication, reward on motivation. The influence of leadership, communication, reward, motivation on performance. The influence of leadership, communication and reward on performance through motivation. The population in this study were employees of the Regional Coordinating Board II of Bojonegoro, East Java Provincial Government, amounting to 34 people with a sample of 33 people. Data collection techniques using questionnaires and documentation. The data analysis technique used path analysis. The results of the study can be explained that the performance of employees is in very good condition, while for work motivation, leadership, communication and reward are in good condition. Leadership and giving rewards do not have a significant effect on motivation. Communication has a significant effect on motivation. Leadership, communication and motivation have a significant effect on performance. Rewards do not have a significant effect on performance. Leadership and rewarding do not have a significant effect on performance through motivation. Communication has a significant effect on performance through motivation.
\end{abstract}

Keywords: Leadership, Communication, Reward, Motivation and Performance.

\section{PENDAHULUAN}

Kinerja merupakan hasil pada pekerjaan yang sudah dikerjakan, dimanapekerjaan tersebut dapat berupa fisik ataupun non fisik (Nawawi dalam Widodo, 2015:131). Kinerja menjadi faktor yang daapt mempengaruhi dan memiliki peran yang sangat penting dalam pencapaian tujuan dalam organisasi yang memegang peranan penting dalam mencapai tujuan organisasi maupun tujuan individu. Organisasi akan mengalami kesulitan dalam pencapai tujuannya apabila tidak ada pegawai yang berkinerja baik.

Permasalahan yang terjadi mengenai kinerja pegawai Badan Koordinasi Wilayah II Bojonegoro 
Pemprov Jatim merupakan masalah yang perlu diperhatikan seperti berapa banyak pekerjan pegawai yang mendapatkan kekurangan nilai dalam menunjang keterselesaian pekerjaan, masih rendahnya kualitas kerja yang ditandai dengan beberapa hasil pekerjaan masih belum optimal, menurunnya semangat kerja, inisiatif pegawai yang masih rendah, pegawai masih belum dapat menggunakan waktu kerja yang diberikan dengan sebaik-baiknya, dimana hal ini akan menghambat kinerja pada Badan Koordinasi Wilayah II Bojonegoro Pemprov Jatim pada masa yang akan dating yang pada akhirnya tanggung jawab pegawai dalam penjelesaian pekerjaan tidak terbentuk sesuai dengan harapan, Oleh karena itu dengan memiliki pegawai yang berkualitas dapat meningkatkan kinerja pegawai sehingga tujuan organisasi dapat tercapai. Berbagai strategi yang dapat dijalankan oleh Badan Koordinasi Wilayah II Bojonegoro Pemprov Jatim untuk meningkatkan kinerja pegawai, diantaranya dengan memberikan motivasi, penerapan kemimpinan yang sesuai, komunikasi dan pemberian reward.

Mengingat motivasi pegawai sangat penting pada suatu organisasi, maka dalam organisasi tersebut harus lebih memperhatikan pegawai dengan serius pada setiap tugas yang diberikan untuk dikerjakan sehingga usaha untuk mencapai tujuan organisasi dapat terlaksana dengan baik. Pegawai dengan motivasi yang tinggi dalam melaksanakan pekerjaan, maka dia senantiasa melakukan pekerjaan dengan semangat tinggi untuk menyelesaikan pekerjaan yang dibebankan kepadanya. Sebaliknya, Pegawai yang memiliki motivasi terhadap pekerjaan yang rendah, dia tidak akan bersemangat dalam melaksanakan pekerjaan, sehingga akan cepat menyerah dan akan selalu mengalami berbagai macam kesulitan untuk penyelesaian pekerjaannya.

Motivasi sebagai bagian dalam upayan untuk peningkatan kinerja pegawai. Adapun kinerja maupun motivasi kerja menjadi elemen yang korelatif dan konstruktif yang saling melekat dan mensyaratkan sehingga tidak bias dilepaskan dengan bavariabel yang lainnya. Apabila pegawai tidak memiliki motivasi yang tinggi dalam bekerja, maka kinerja pegwai akan juga ikut rendah dan begitu juga sebaliknya apabila pegawai tersebut memiliki motivasi kerja yang baik, maka akan meningkatkan kinerja pegawai.

Keberhasilan organisasi dalam mencapai tujuannya tidak dapat dilepaskan dari peran pemimpinnya. Kepemimpinan memiliki peran yang penting dalam organisasi terutama pada organisasi pemerintahan Badan Koordinasi Wilayah II Bojonegoro Pemprov Jatim. Karena kepemimpinan yang diterapkan dapat mempengaruhi berhasil tidaknya organisasi dalam mencapai tujuannya. Seorang pemimpin bukan sematamata sebagai obyek dalam pencapaian tujuan, tetapi sekaligus menjadi subyek atau pelaku.

Pada umumnya setiap organisasi akan menggantungkan kelancaran kegiatannya kepada kualitas dari kepemimpinan, hal ini dikarenakan pimpinan dapat mengatur para pegawai supaya melakukan pekerjaannya demi tercapainya tujuan organisasi. Dengan demikian pada Badan Koordinasi Wilayah II Bojonegoro Pemprov Jatim memerlukan sosok pimpinan yang dapat memberikan inspirasi, motivasi 
dan dapat menggerakkan pawa bawahannya dengan efektif serta efisien agar dapat memotivasi pegawainya sehingga kinerja pegawai akan meningkat.

Komunikasi diperlukan untuk mengetahui apakah manajemen dalam organisasi sudah bertindak secara efektif apa belum efektif. Pada suatu organisasi biasanya ada berbagai cara komunikasi yang perlu diperhatikan dalam kelangsungan perjalannya organisasi. Di antara kedua belah pihak antara pimpinan dan bawahan maupun antar rekan kerja harus menjalin komunikasi timbal balik ataupun yang biasa disebut komunikasi dengan dua arah. Dengan demikian baik atasan maupun bawahan harus dapat paham dengan benar mengenai komunikasi dengan tujuan penyampaian informasi dapat tersampaikan dengan baik dan lancar sehingga kinerja pegawai dapat meningkat

\section{TINJAUAN PUSTAKA Kinerja}

Wirawan dalam Abdullah (2016:3) memberikan pengertian mengenai kinerja yang berasal dari bahasa inggris adalah perfomance, dimana kinerja diartikan sebagai hasil pekerjaan yang dihasilkan dari beberapa indikator atau fungsi dari kerjaan yang dilakukan pada suatu periode waktu yang telah ditentukan. Mangkunegara

(2016:67) menjelaskan pengertian kinerja (prestasi kerja) adalah hasil kerja secara kualitas dan kuantitas yang dicapai oleh seorang pegawai dalam melaksanakan tugasnya sesuai dengan tanggung jawab yang diberikan kepadanya. Kemudian pengertian menurut Nawawi dalam Widodo (2015:131) yang menjelaskan kinerja merupakan hasil pada pekerjaan yang sudah dikerjakan, dimanapekerjaan tersebut dapat berupa fisik ataupun non fisik. Mangkunegara (2016:10) menyatakan bahwa indikator yang dapat digunkan dalam mengukur kinerja pegawai antara lain: 1) Kualitas kerja, 2) Kuantitas Kerja, 3) Tangung jawab, 4) Inisiatif, 5) Kerja sama, 6) Ketaatan.

Pamela \& Oloko (2015) mengartikan motivasi sebagai kunci bagi kesuksesan organisasi dalam menjaga keberlangsungan setiap bidang pekerjaan yang ada di organisasi tersebut dengan persepsepsi agar dapat bertahan hidup sehingga akan memiliki keinginan yang kuat karena seseorang yang termotivasi akan mempunyai suatu energy dalam mengerahkan seluruh kemampuannya dan dapat bertahan untuk dapat menghasilkan suatu pekerjaan dengan maksimal. Setiap individu yang mempunyai motivasi dalam bekerja dapat menyelesaiakan setiap pekerjaan yang diberikan kepadanya, meskipun pada proses pelaksanaannya terhalang oleh berbagai macam rintangan yang terkadang rintang tersebut tidaklah sedikit. Sedangkan menurut Ardana dalam Linawati (2015) motivasi meupakan perasaan emosional dalam diri, dimana motivasi tersebut dapat ditingkatkan oleh pribadinya sendiri ataupun melalui dorongan dari luar untuk dapat mempengaruhi hasil dari pekerjaan yang menjadi tanggung jawabnya.

Menurut Wibowo (2017:162), indikator motivasi adalah sebagai berikut: 1) Kebutuhan untuk berprestasi, 2) Kebutuhan memperluas pergaulan, 3) Kebutuhan untuk menguasai sesuatu pekerjaan 


\section{Kepemimpinan}

Pengertian dari kepemimpinan sebagaimana dijelaskan oleh Stogdi dalam Sutikno (2014:15) yaitu kepemimpinan merupakan suatu konsep yang ada dalam manajemen yang kemiudian dapat dirumuskan kedalam bermacam-macam pengertian tergantung dari bagaimana pola dari darimana sudut arah pemikirinya. Soekanto (2012) menjelaskan kepemimpinan merupakan kemampuan dari leader dalam memberikan pengaruh kepada orang lain atau pengikutnya. Kepemimpinan adalah suatu proses yang dikerjakan seseorang dalam mempengaruhi sekelompok orang agar tujuan organisasi dapat tercapai (Robbins dan Coulter, 2015). Hasibuan (2011:171) menyebutkan pemimpin pada pengimplementasian kekuasaanya harus dapat adil dan dapat mengatur dengan baik setiap bawahan yang dipimpinan dan organisasi tertentu, kepemimpinan dapat diukur dalam beberap indikator, diantaranya: 1) Kemampuan dalam melakukan pembinaan hubungan dan kerjasama yang baik, 2) efektivitas, 3) pengambilan kepuasan dengan partisipatif, 4) pendelegasian tugas berkaitan dengan waktu, 5) pendelegasian tugas berkaitan dengan wewenang.

\section{Komunikasi}

$$
\text { Mangkunegara }
$$

menjelaskan komunikasi merupakan proses untuk memdahkan suatu informasi, ide, pengertian dari satu orang ke orang ke orang lainnya agar tujuan dari penyampaian informasi tersebut dapat tersalurkan dengan baik. Menurut Daft dalam Mangkunegara (2016:76) pengertian dari komunikasi sebagai suatu proses dalam penyampaian atau pertukaran informasi, dimana informasi tersebut dapat dimengerti dan dipahami oleh lawan orang yang diajak berkomunikasi. Pada umunya komunikasi digunakan untuk mendorong ataupun mempengaruhi seseorang pegawai dalam penyelesaian suatu pekerjaan. Ada 2 elemen penting dalam melakukan komunikasi yaitu pemberi informasi dan penerima informasi. Pemberi informasi merupakan seseorang yang ingin menyampaikan informasi maupun penyampaian pemikiran atau perasan emosinya kepada orang lain. Sedangkan penerima informasi merupakan seseorang yang menerima informasi dari orang yang menyampaikan irformasi yang dapat memberikan timbal balik juga kepada pemberi informasi

Menurut Charoenngam, Nongluck dan Jabin dalam Mangkunegara (2016), ada berbagai macam indikator dalam mengukur komunikasi, antara lain: 1) kebijaksanaan dan kesopanan, yaitu komunikasi yang dilakukan dengan penggunaan bahasa dan ketepatan dalam pemilihan kata serta pembawaan yang halus juga sopan, 2) penerimaan dalam feed back atau umpan balik, yaitu penerimaan informasi kemudian menanggapi dari isi informasi tersebut, 3) berbagi informasi, dimana informasi dapat dibagikan kepada semua pegawai baik dari bawahan maupun dengan atasan, 4) memberikan tugas, yaitu pemberian informasi mengenai isi dari tugas yang diberikan, 5) pengurangan tugas yang tidak pasti, yaitu penyampaian informasi dengan pemilihan mana saja tugas yang perlu dikerjakan agar dapat selesai sesuai dengan yang diperintahkan.

\section{Reward}

Reward adalah hadiah, dimana hadiah ini merupakan suatu bentuk 
teori penguatan positif yang bersumber dari teori behavioristik. Arikunto (2016:160) menyatakan Reward merupakan pemberian suatu hadiah kepada pegawai karena telah memenuhi standarat prestasi tertentu yang telah ditetapkan. adapaun Sastrohadiwiryo (2013:17) juga menambahkan bahwa reward atau Penghargaan adalah suatu bentuk pemberian dari imbalan atas balas jasa kepada pegawai karena sudah memberikan sumbangan pikiran dan tenaganya dalam mencapai tujuan perusahaan. Adapun indikator dalam mengukur reward kepada para pegawai Kadarisman (2012:122) menjelaskan sebagai berikut: 1) Upah, 2) Gaji, 3) Insentif, 4) Tunjangan, 5) Penghargaan Interpersonal

\begin{abstract}
METODE PENELITIAN
Jenis penelitian ini explanatory research dengan pendekatan kuantitatif. Populasi dalam penelitian ini adalah pegawai Badan Koordinasi Wilayah II Bojonegoro, Pemprov Jatim yang berjumlah 34 orang. Sampel dalam penelitian ini adalah semua pegawai Badan Koordinasi Wilayah II Bojonegoro, Pemprov Jatim yang berjumlah 33 orang. Teknik pengumpulan data menggunakan kuesioner dan dokumentasi. Teknik analisis data menggunakan path analisis.
\end{abstract}

\section{HASIL DAN PEMBAHASAN}

Dari hasil perhitingan program SPSS yang dilakukan diperoleh hasil statistic deskriptif pada tabel sebagai berikut:

Promosi

Tabel 1

Descriptive Statistics

\begin{tabular}{lcrrrr}
\hline \multicolumn{1}{c}{ Variabel } & N & Minimum & Maximum & Mean & $\begin{array}{c}\text { Std. } \\
\text { Deviation }\end{array}$ \\
\hline Kinerja & 33 & 3.67 & 4.83 & 4.2218 & .36566 \\
\hline Motivasi & 33 & 3.00 & 5.00 & 4.1415 & .48554 \\
\hline Kepemimpinan & 33 & 3.40 & 4.60 & 3.9152 & .29168 \\
\hline Komunikasi & 33 & 3.00 & 4.80 & 4.0788 & .47418 \\
\hline Reward & 33 & 3.33 & 4.50 & 3.8742 & .30308 \\
\hline Valid N (listwise) & 33 & & & & \\
\hline
\end{tabular}

Sumber : Hasil Pengolahan Data, 2021

Dari hasil deskripsi varibel pada tabel di atas dapat diketahui sebagai berikut:

1. Deskripsi variabel kinerja memiliki nilai mean sebesar 4.22 , nilai mean tersebut berada pada interval kelas 4.21 - 5.00 sangat baik. Hal ini menunjukkan bahwa kondisi variabel kinerja pegawai Kantor Bakorwil II Bojonegoro dalam kondisi yang sangat baik.

2. Deskripsi variabel motivasi memiliki nilai mean sebesar 4.14, nilai mean tersebut berada pada interval kelas 4.21 - 5.00 sangat baik. Hal ini menunjukkan bahwa kondisi variabel motivasi kerja pegawai Kantor Bakorwil II Bojonegoro dalam kondisi yang baik.

3. Deskripsi variabel kepemimpinan memiliki nilai mean sebesar 3.91, nilai mean tersebut berada pada interval kelas 4.21 - 5.00 sangat baik. Hal ini menunjukkan bahwa kondisi variabel kepemimpinan di Kantor Bakorwil II Bojonegoro dalam kondisi yang baik.

4. Deskripsi variabel komunikasi memiliki nilai mean sebesar 4.08, 
nilai mean tersebut berada pada interval kelas 4.21 - 5.00 sangat baik. Hal ini menunjukkan bahwa kondisi variabel komunikasi di Kantor Bakorwil II Bojonegoro dalam kondisi yang baik.

5. Deskripsi variabel reward memiliki nilai mean sebesar 3.87 , nilai mean tersebut berada pada interval kelas 4.21 - 5.00 sangat baik. Hal ini menunjukkan bahwa kondisi variabel reward di Kantor Bakorwil II Bojonegoro dalam kondisi yang baik.

Langkah pengujian analisis jalur dalam penelitian ini dibagi menjadi dua yaitu pengujian jalur 1 pengaruh kepemimpinan, komunikasi, dan Reward terhadap motivasi kerja dan jalur 2 pengaruh Kepemimpinan, komunikasi, Reward dan motivasi kerja terhadap kinerja pegawai.

1. Jalur pertama pengaruh kepemimpinan, komunikasi, dan reward terhadap motivasi kerja

Besarnya

pengaruh

Kepemimpinan, komunikasi, dan Reward terhadap motivasi kerja dapat diketahui melalui model structural jalur pertama yang dapat dilihat pada hasil model summary sebagai berikut:

Tabel 2

Model Summary Pengaruh Kepemimpinan, Komunikasi, Dan Reward Terhadap Motivasi Kerja

\begin{tabular}{lcccc}
\hline Model & $\mathrm{R}$ & $\begin{array}{c}\mathrm{R} \\
\text { Square }\end{array}$ & $\begin{array}{c}\text { Adjusted R } \\
\text { Square }\end{array}$ & $\begin{array}{c}\text { Std. Error of the } \\
\text { Estimate }\end{array}$ \\
\hline 1 & $.520^{\mathrm{a}}$ & .270 & .194 & .43577 \\
\hline a. Predictors: (Constant), Reward, & Kepemimpinan, Komunikasi
\end{tabular}

Sumber : Hasil Pengolahan Data, 2021

Dari hasil analisis pada tabel di atas dapat diketahui nilai R Square sebesar 0.270. Artinya motivasi kerja pegawai Kantor Bakorwil II Bojonegoro dapat dipengaruhi oleh variabel kepemimpinan, komunikasi, dan reward sebesar $27.0 \%$ dan sisanya sebesar $73 \%$ motivasi kerja bisa mendapat pengaruh selain dari variabel pada penelitian ini dapat dipengaruhi oleh variabel lain.

Kemudian untuk melihat seberapa besar pengaruh variabel Kepemimpinan, komunikasi, dan Reward terhadap motivasi kerja pegawai Kantor Bakorwil II Bojonegoro dapat diketahui dari hasil analisis coefficients pada tabel di bawah ini:

Tabel 3

Coefficients Pengaruh Kepemimpinan, Komunikasi, Dan Reward Terhadap Motivasi Kerja

\begin{tabular}{|c|c|c|c|c|c|c|}
\hline \multirow{2}{*}{\multicolumn{2}{|c|}{ Model }} & \multicolumn{2}{|c|}{$\begin{array}{c}\text { Unstandardized } \\
\text { Coefficients }\end{array}$} & \multirow{2}{*}{$\begin{array}{c}\begin{array}{c}\text { Standardized } \\
\text { Coefficients }\end{array} \\
\text { Beta }\end{array}$} & \multirow[t]{2}{*}{$\mathrm{t}$} & \multirow[t]{2}{*}{ Sig. } \\
\hline & & $\mathrm{B}$ & Std. Error & & & \\
\hline \multirow[t]{4}{*}{1} & (Constant) & 1.589 & 1.123 & & 1.415 & 168 \\
\hline & Kepemimpinan & .189 & .357 & .114 & .529 & .601 \\
\hline & Komunikasi & .426 & .199 & .416 & 2.142 & .017 \\
\hline & Reward & .401 & .340 & .250 & 1.181 & .247 \\
\hline
\end{tabular}

a. Dependent Variable: Motivasi

Sumber : Hasil Pengolahan Data, 2021 
Dari hasil analisis pada tabel di atas dapat diketahui pengaruh Kepemimpinan $\left(\mathrm{X}_{1}\right)$, komunikasi $\left(\mathrm{X}_{2}\right)$, dan Reward $\left(\mathrm{X}_{3}\right)$ terhadap motivasi kerja (Z) Kantor Bakorwil II Bojonegoro didapatkan bentuk persamaan model struktural jalur pertama sebagai berikut:

$$
\begin{gathered}
Z=0.114 X_{1}+0.416 X_{2}+ \\
0.250 X_{3}+0.730
\end{gathered}
$$

Dari persamaan struktural pada jalur pertama di atas, dapat diketahui pengaruh Kepemimpinan $\left(\mathrm{X}_{1}\right)$, komunikasi $\left(\mathrm{X}_{2}\right)$, dan Reward $\left(\mathrm{X}_{3}\right)$ terhadap motivasi kerja (Z) Kantor Bakorwil II Bojonegoro untuk melakukan pengujian hipotesis sebagai berikut:

a. Kepemimpinan terhadap motivasi kerja

Pengujian hipotesis yang menyatakan bahwa Kepemimpinan memiliki pengaruh yang tidak signifikan terhadap motivasi kerja pegawai di Badan Koordinasi Wilayah II Bojonegoro Pemprov Jatim dapat dilihat dari nilai beta yang sudah di standarkan sebesar 0.114 kemudian didapatkan juga nilai $\mathrm{t}$ sebesar 0.529 yang memiliki signifikansi 0.601, dimana (sig > 0.05), sehingga dinyatakan bahwa kepemimpinan tidak berpengaruh signifikan pada motivasi pegawai Kantor Bakorwil II Bojonegoro.

b. Komunikasi terhadap motivasi kerja

Pengujian hipotesis yang menyatakan bahwa komunikasi memiliki pengaruh yang signifikan terhadap motivasi kerja pegawai di Badan Koordinasi Wilayah II Bojonegoro Pemprov Jatim dapat dilihat dari nilai beta yang sudah di standarkan sebesar 0.416 kemudian didapatkan juga nilai t 2.142 yang memiliki signifikansi 0.017, dimana (sig $<0.05$ ), sehingga dinyatakan bahwa komunikasi mempunyai pengaruh yang signifikan pada motivasi kerja pegawai Kantor Bakorwil II Bojonegoro.

c. Reward terhadap motivasi kerja Pengujian hipotesis yang menyatakan bahwa reward memiliki pengaruh yang signifikan terhadap motivasi kerja pegawai di Badan Koordinasi Wilayah II Bojonegoro Pemprov Jatim dapat dilihat dari nilai beta yang sudah di standarkan sebesar 0.250 kemudian didapatkan juga nilai t 1.181 yang memiliki signifikansi 0.247, dimana (sig $>0.05$ ), sehingga dinyatakan bahwa pemberian reward tidak berpengaruh signifikan terhadap motivasi kerja pegawai Kantor Bakorwil II Bojonegoro.

2. Pengaruh kepemimpinan, komunikasi, reward dan motivasi kerja terhadap kinerja pegawai Besarnya pengaruh kepemimpinan, komunikasi, reward dan motivasi kerja terhadap kinerja pegawai dapat diketahui melalui model structural jalur kedua yang dapat dilihat pada hasil model summary sebagai berikut: 


\section{Tabel 4}

Model Summary Pengaruh Kepemimpinan, Komunikasi, Reward dan Motivasi Kerja Terhadap Kinerja

\begin{tabular}{lcccc}
\hline Model & $\mathrm{R}$ & $\begin{array}{c}\mathrm{R} \\
\text { Square }\end{array}$ & $\begin{array}{c}\text { Adjusted R } \\
\text { Square }\end{array}$ & $\begin{array}{c}\text { Std. Error of the } \\
\text { Estimate }\end{array}$ \\
\hline 1 & $.698^{\mathrm{a}}$ & .487 & .414 & .27989 \\
\hline $\begin{array}{l}\text { a. Predictors: (Constant), Reward, Kepemimpinan, Komunikasi, } \\
\text { Motivasi }\end{array}$ & & &
\end{tabular}

Sumber : Hasil Pengolahan Data, 2021

Hasil yang diperoleh pada tabel tersebut menunjukkan nilai $\mathrm{R}^{2} \quad$ : 0.487 . Artinya kinerja pegawai Kantor Bakorwil II Bojonegoro dapat dipengaruhi oleh variabel kepemimpinan, komunikasi, dan reward sebesar 48.7\% dan sisanya sebesar $51.3 \%$ kinerja pegawai dapat dipengaruhi oleh variabel lain. Kemudian untuk mengetahui pengaruh variabel kepemimpinan, komunikasi, reward dan motivasi kerja terhadap kinerja pegawai Kantor Bakorwil II Bojonegoro dapat dilihat pada tabel berikut:

Tabel 5

Coefficients Pengaruh Pengaruh Kepemimpinan, Komunikasi, Reward dan Motivasi Kerja Terhadap Kinerja

\begin{tabular}{|c|c|c|c|c|c|c|}
\hline \multirow{2}{*}{\multicolumn{2}{|c|}{ Model }} & \multicolumn{2}{|c|}{$\begin{array}{l}\text { Unstandardized } \\
\text { Coefficients }\end{array}$} & \multirow{2}{*}{$\begin{array}{c}\text { Standardized } \\
\text { Coefficients } \\
\text { Beta } \\
\end{array}$} & \multirow[t]{2}{*}{$\mathrm{t}$} & \multirow[t]{2}{*}{ Sig. } \\
\hline & & B & Std. Error & & & \\
\hline \multirow[t]{5}{*}{1} & (Constant) & 2.396 & .746 & & 3.214 & .003 \\
\hline & Kepemimpinan & .393 & .230 & .314 & 1.707 & .039 \\
\hline & Komunikasi & .395 & .138 & .513 & 2.874 & .008 \\
\hline & Reward & .195 & .223 & .162 & .873 & .390 \\
\hline & Motivasi & .241 & .119 & .320 & 2.021 & .019 \\
\hline
\end{tabular}

a. Dependent Variable: Motivasi

Sumber : Hasil Pengolahan Data, 2021

Dari hasil analisis pada tabel 4.18 di atas dapat diketahui pengaruh Kepemimpinan $\left(\mathrm{X}_{1}\right)$, komunikasi $\left(\mathrm{X}_{2}\right)$, Reward $\left(\mathrm{X}_{3}\right)$ dan motivasi kerja (Z) terhadap Kinerja pegawai (Y) Kantor Bakorwil II Bojonegoro didapatkan bentuk persamaan model struktural jalur pertama sebagai berikut:

$$
\mathrm{Y}=0.314 \mathrm{X}_{1}+0.513 \mathrm{X}_{2}+
$$

$0.162 X_{3}+0.320 Z+0.513$

Dari persamaan struktural pada jalur pertama di atas, dapat diketahui pengaruh Kepemimpinan dan komunikasi serta Reward $\left(X_{3}\right)$ terhadap motivasi kerja Kantor Bakorwil II Bojonegoro untuk melakukan pengujian hipotesis sebagai berikut:

a. Kepemimpinan terhadap kinerja pegawai

Pengujian hipotesis yang mengatakan bahwa kepemimpinan mempunyai pengaruh langsung signifikan terhadap kinerja pegawai pegawai di Badan Koordinasi Wilayah II Bojonegoro Pemprov Jatim dapat dilihat 
dari nilai beta yang sudah di standarkan sebesar 0.314 kemudian didapatkan juga nilai t 1.707 yang memiliki signifikansi 0.039 , dimana (sig $<0.05$ ), maka hipotesis dapat diterima, bahwa kepemimpinan berpengaruh signifikan terhadap kinerja pegawai Kantor Bakorwil II Bojonegoro.

b. Komunikasi terhadap kinerja Pengujian hipotesis yang mengatakan bahwa komunikasi mempunyai pengaruh langsung signifikan terhadap kinerja pegawai di Badan Koordinasi Wilayah II Bojonegoro Pemprov Jatim dapat dilihat dari nilai beta yang sudah di standarkan sebesar 0.513 kemudian didapatkan juga nilai t 2.874 yang memiliki signifikansi 0.008 , dimana (sig $<0.05$ ), maka Ha diterima dan Ho ditolak. Dengan demikian hipotesis tersebut diterima, sehingga dapat dikatakan bahwa komunikasi mempunyai pengaruh yang signifikan terhadap kinerja pegawai Kantor Bakorwil II Bojonegoro.

c. Reward terhadap kinerja

Pengujian hipotesis yang mengatakan bahwa reward mempunyai pengaruh langsung signifikan terhadap kinerja pegawai di Badan Koordinasi Wilayah II Bojonegoro Pemprov Jatim dapat dilihat dari nilai beta yang sudah di standarkan sebesar 0.162 kemudian didapatkan juga nilai $\mathrm{t} \quad 0.873$ yang memiliki signifikansi 0.390 , dimana (sig $>0.05$ ), maka hipotesis tidak dapat diterima dan disimpulkan bahwa pemberian reward tidak berpengaruh signifikan terhadap kinerja pegawai Kantor

Bakorwil II Bojonegoro.

d. Motivasi kerja terhadap kinerja pegawai

Pengujian hipotesis yang mengatakan bahwa motivasi kerja mempunyai pengaruh yang signifikan terhadap kinerja pegawai pegawai di Badan Koordinasi Wilayah II Bojonegoro Pemprov Jatim dapat dilihat dari nilai beta yang sudah di standarkan sebesar 0.320 kemudian didapatkan juga nilai t 2.021 yang memiliki signifikansi 0.0.19, dimana (sig $<0.05$ ), maka hipotesis dapat diterima dan disimpulkan bahwa motivasi kerja berpengaruh signifikan terhadap kinerja pegawai Kantor Bakorwil II Bojonegoro.

3. Pengaruh kepemimpinan, komunikasi, reward terhadap kinerja pegawai melalui dan motivasi kerja

a. Kepemimpinan terhadap kinerja dengan motivasi kerja sebagai variabel intervening

Kepemimpinan tidak berpengaruh terhadap motivasi pada jalur pertama, kemudian kepemimpinan berpengaruh signifikan terhadap kinerja pada jalur kedua, begitu juga motivasi yang berpengaruh terhadap kinerja pada jalur kedua. Dengan demikian didapatkan hasil kepemimpinan tidak berpengaruh signifikan terhadap kinerja pegawai melalui motivasi di Badan Koordinasi Wilayah II Bojonegoro Pemprov Jatim. Kemudian untuk mengetahui besarnya kontribusi pengaruh kepemimpinan terhadap kinerja pegawai dengan motivasi kerja 
sebagai variabel intervening di Badan Koordinasi Wilayah II Bojonegoro Pemprov Jatim didapatkan sebesar 0.35048 atau sebesar $35.05 \%$.

b. Komunikasi terhadap kinerja dengan motivasi kerja sebagai variabel intervening

Komunikasi mempunyai pengaruh pada motivasi pada jalur pertama, kemudian komunikasi berpengaruh signifikan terhadap kinerja pada jalur kedua, begitu juga motivasi yang berpengaruh terhadap kinerja pada jalur kedua. Dengan demikian didapatkan hasil komunikasi berpengaruh signifikan terhadap kinerja pegawai dengan motivasi kerja sebagai variabel intervening di Badan Koordinasi Wilayah II Bojonegoro Pemprov Jatim. Kemudian untuk mengetahui besarnya kontribusi pengaruh komunikasi pada kinerja pegawai melalui motivasi kerja di Badan Koordinasi Wilayah II Bojonegoro Pemprov Jatim sebesar 0.5802 atau sebesar $58.02 \%$.

c. Reward terhadap kinerja dengan motivasi kerja sebagai variabel intervening

Reward berpengaruh terhadap motivasi pada jalur pertama, kemudian reward tidak berpengaruh signifikan terhadap kinerja pada jalur kedua, begitu juga motivasi yang berpengaruh terhadap kinerja pada jalur kedua. Dengan demikian didapatkan hasil reward tidak berpengaruh signifikan terhadap kinerja pegawai melalui motivasi di Badan Koordinasi Wilayah II Bojonegoro
Pemprov Jatim. Kemudian untuk mengetahui besarnya kontribusi pengaruh reward padap kinerja pegawai melalui motivasi kerja sebagai variabel intervening di Badan Koordinasi Wilayah II Bojonegoro Pemprov Jatim sebesar 0.2420 atau sebesar $24.20 \%$.

\section{SIMPULAN DAN SARAN Simpulan}

Berdasarkan pada hasil analisis data dan pembahasan yang telah dilakukan, maka dapat diambil kesimpulan sebagai berikut:

1 Kinerja pegawai Kantor Bakorwil II Bojonegoro dalam kondisi yang sangat baik, sedangkan untuk motivasi kerja, kepemimpinan, komunikasi dan pemberian reward di Kantor Bakorwil II Bojonegoro semuanya berada pada kondisi yang baik

2 Kepemimpinan tidak berpengaruh dengan signifikan terhadap motivasi kerja pegawai di Badan Koordinasi Wilayah II Bojonegoro Pemprov Jatim.

3 Komunikasi berpengaruh signifikan pada motivasi kerja pegawai di Badan Koordinasi Wilayah II Bojonegoro Pemprov Jatim.

4 Pemberian reward tidak berpengaruh signifikan pada motivasi kerja pegawai di Badan Koordinasi Wilayah II Bojonegoro Pemprov Jatim.

5 Kepemimpinan berpengaruh signifikan pada kinerja pegawai di Badan Koordinasi Wilayah II Bojonegoro Pemprov Jatim.

6 Komunikasi berpengaruh signifikan pada kinerja pegawai di Badan Koordinasi Wilayah II Bojonegoro Pemprov Jatim. 
7 Pemberian reward tidak berpengaruh signifikan pada kinerja pegawai di Badan Koordinasi Wilayah II Bojonegoro Pemprov Jatim.

8 Motivasi kerja berpengaruh signifikan pada kinerja pegawai di Badan Koordinasi Wilayah II Bojonegoro Pemprov Jatim.

9 Kepemimpinan tidak berpengaruh signifikan pada melalui motivasi kerja di Badan Koordinasi Wilayah II Bojonegoro Pemprov Jatim.

10 Komunikasi tidak berpengaruh signifikan pada kinerja pegawai melalui motivasi kerja di Badan Koordinasi Wilayah II Bojonegoro Pemprov Jatim.

11 Pemberian reward tidak berpengaruh signifikan pada kinerja pegawai melalui motivasi di Badan Koordinasi Wilayah II Bojonegoro Pemprov Jatim.

\section{Saran}

Adapun penulis bisa memberikan beberapa saran sehubungan pada hasil penelitian mengenai pengaruh kepemimpinan dan komunikasi serta pemberian reward terhadap kinerja pegawai Badan Koordinasi Wilayah II Bojonegoro Pemprov Jatim melalui motivasi kerja antara lain:

1. Untuk meningkatkan kinerja pegawai Badan Koordinasi Wilayah II Bojonegoro Pemprov Jatim perlu peningkatan pada komunikasi karena komunikasi memiliki pengaruh yang signifikan terhadap kinerja ataupun melalui motivasi kerja. Peningkatan komunikasi dapat dilakukan dengan cara:

menerapkan kesopanan dalam bekerja, menerima umpan balik, berbagi informasi untuk kepentingan bersama, dapat memberikan informasi tugas dengan baik, dapat mengurangi ketidakpastian tugas.

2. Motivasi juga tidak kalah penting untuk ditingkan karena juga memiliki pengaruh yang signifikan terhadap kinerja pegawai. Peningkatan motivasi dapat dilakukan dengan cara memfasilitasi pegawai untuk menguasai sesuatu pekerjaan untuk meningkatkan kemampuan pegawai sehingga pegawai menjadi lebih termotivasi dalam bekerja.

3. Meskipun kepemimpinan dan pemberian reward tidak mempunyai pengaruh yang signifikan terhadapa motivasi kerja, akan tetapi berpengaruh signifikan terhadap kinerja pegawai. Peningkatan kepemimpinan dapat dilakukan dengan meningkatkan kemampuan partisipatif pimpinan dan pemberian reward dapat dilakukan dengan penyesuaian dan proporsional tunjangan yang diterima pegawai.

\section{DAFTAR PUSTAKA}

Abdullah, M. 2016. Manajemen dan Evaluasi Kinerja Karyawan. Yogyakarta : Penerbit Aswaja Pressindo.

Arikunto, Suharsimi. 2016. Manajemen Penelitian. Jakarta : Rineka Cipta.

Hasibuan, Malayu S.P. 2011. Manajemen Dasar, Pengertian, dan Masalah, Edisi Revisi, Bumi Aksara:Jakarta.

Kadarisman, M. 2012. Manajemen Pengembangan. Sumber Daya 
Manusia. Jakarta : Rajawali

Pers.

Linawati. 2015. Pengaruh Motivasi, Kompetensi, Kepemimpinan, Dan Lingkungan Kerja Terhadap Kinerja Karyawan (Studi Pada PT. Herculon Carpet Semarang). Jurnal Kajian Akuntansi dan Bisnis Vol. 1 No. 1 2015 : STIE Widya Manggala

Mangkunegara, AA. Anwar Prabu. 2016. Manajemen Sumber Daya Manusia Perusahaan. Bandung : PT. Remaja Rosdakarya

Pamela, A.O., \& Oloko. 2015. Effect of motivation on employee performance of commercial banks in kenya : A case study of Kenya Commercial Bank in Migori County. Journal of Human Resource Studies 5 (2).

Robbins, P. Stephen dan Coulter, Mary. 2015. Manajemen diterjemahkan oleh Bob Sabran, Wibi Hardani. Jakarta: Erlangga

Sastrohadiwiryo, Siswanto. 2013. Manajemen Tenaga Kerja Indonesia. Bandung: Bumi Aksara.

Soekanto, Soerjono. 2012. Hukum Adat Indonesia. Jakarta: PT. Raja Grafindo Persada

Sutikno, Sobry. 2014. Metode \& Model-Model Pembelajaran Menjadikan Proses Pembelajaran Lebih Variatif, Aktif, Inovatif, Efektif, dan
Menyenangkan. Lombok: Holistica

Wibowo. 2017. Manajemen Kinerja . Edisi Keempat . Jakarta : Rajawali Pers.

Widodo, S., Eko. 2015. Manajemen Pengembangan Sumber Daya Manusia. Yogyakarta: Pustaka Pelajar. 